\title{
SMIRIVANJE PROMETA U GRADOVIMA
}

\section{Ružica Lukač}

Sveučilište Josipa Jurja Strossmayera u Osijeku, Građevinski fakultet Osijek, studentica

\section{Sanja Dimter}

Sveučilište Josipa Jurja Strossmayera u Osijeku, Građevinski fakultet Osijek, izvanredna profesorica

Sažetak: Koncept „smirivanja prometa“ temelji se na zahtjevu povećanja sigurnosti prometa, a postiže se smanjivanjem brzine kretanja vozila u stambenim zonama i u blizini škola i dječjih vrtića te poboljšanju preglednosti. Smirivanjem prometa moguće je postići i povećanje udobnosti i sigurnosti kod pješaka te smanjenje neposrednih štetnih utjecaja na okoliš: smanjenje razine buke i onečišćenja zraka. Za postizanje postavljenog cilja treba provesti čitav niz postupaka koji se sastoje od preuređenja postojeće cestovne mreže, postavljanja posebne opreme i signalizacije za smirivanje prometa te uvođenja dosljedne i učinkovite regulative. U članku su prikazane različite mjere smirivanja prometa uvažavajući europska i domaća iskustva te dan osvrt na hrvatsku zakonsku i tehničku regulativu iz ovog područja.

Ključne riječi: brzina vozila; smirivanje prometa; mjere, zakonska i tehnička regulativa

\section{TRAFFIC CALMING IN THE CITIES}

\begin{abstract}
The concept of "traffic calming" is based on a request to increase traffic safety which is achieved by reducing the speed of vehicles in residential zones and near schools and kindergartens, and improving visibility.Traffic calming can also improve the comfort and safety for pedestrians and reduce the negative impact on the environment: reducing noise and air pollution. Achieving expected goals requires a series of procedures that comprise the refurbishment of the existing road network, installation of special equipment and signs for traffic calming and the introduction of consistent and effective regulation. The article presents various traffic calming measures respecting European and domestic experiences and describes the Croatian legal and technical regulations in this area.
\end{abstract}

Key words: vehicle speed; traffic calming; measures; legal and technical regulations 


\section{Uvod}

Razvitak prometa te visok stupanj motorizacije, uz sve važne prednosti u zadovoljenju potreba mobilnosti stanovnika u gradovima, izaziva i negativnosti među kojima se posebno ističu prometne nesreće. S jedne strane postavlja se zahtjev za pokretljivošću i što većom brzinom, a s druge strane upravo velika brzina kretanja ugrožava sigurnost sudionika u prometu, posebno pješaka, biciklista, djece i hendikepiranih osoba. Brojna istraživanja [1, 2] potvrdila su vrlo usku vezu između brzine kretanja vozila i težine posljedica (povreda) za pješake i bicikliste u prometnim nesrećama. Prema domaćim istraživanjima [1] granična brzina pri kojoj nema težih posljedica za nezaštićene sudionike u prometu iznosi $30 \mathrm{~km} / \mathrm{h}$. Na temelju provedenih inozemnih istraživanja [2], graničnu brzinu između nastanka lakših i težih povreda pješaka i biciklista prilikom nalijetanja vozila čini brzina vožnje od $36 \mathrm{~km} / \mathrm{h}$ (slika 1).

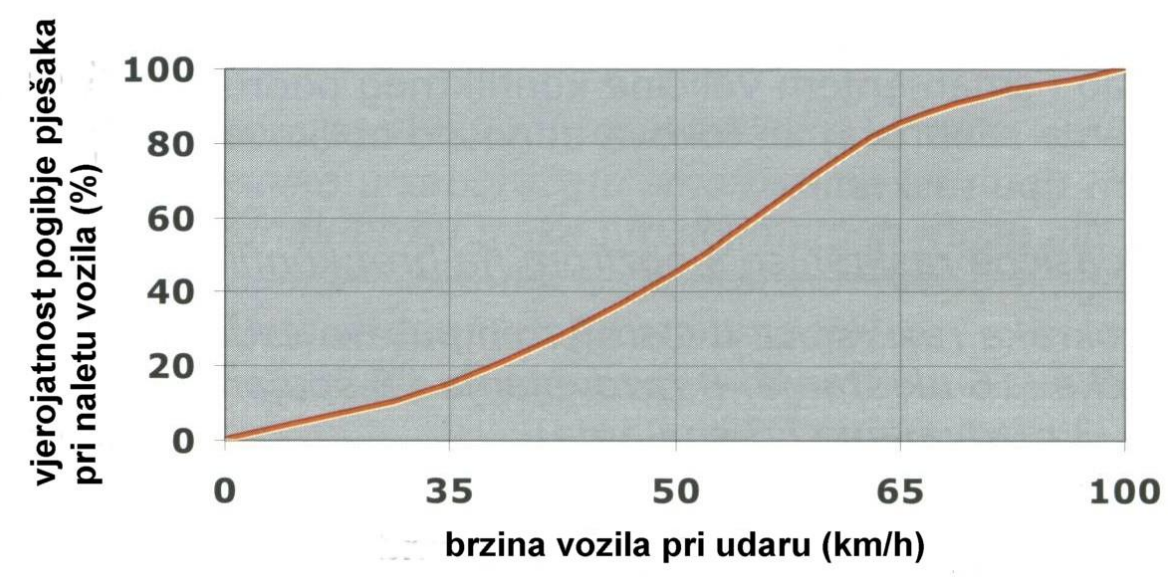

\section{Slika 1 - Utjecaj brzine vožnje na vjerojatnost pogibije pješaka prilikom sudara [2]}

Radi ostvarenja optimalne ravnoteže između pokretljivosti i sigurnosti sudionika u prometu, potrebno je pažljivo osmisliti način vođenja različitih oblika prometa: razdvojiti in ili integrirati. U gradovima, pogotovo njihovim središnjim dijelovima, prednost se daje pješacima i nemotoriziranim sudionicima po mjerilu i zahtjevima koncepta „smirivanja prometa“. Na ovaj način se prometno integriraju osjetljive skupine građana poput pješaka, biciklista, djece i hendikepiranih osoba te se teži svojevrsnom kompromisu: ostvarenju ravnoteže između pokretljivosti, ekologije, energetike i sigurnosti.

Koncept smirivanja prometa temelji se na zahtjevu povećanja sigurnosti prometa: smanjivanju brzine kretanja vozila u stambenim zonama i u blizini škola i dječjih vrtića, poboljšanju vozačeve preglednosti iz vozila te povećanju opće preglednosti. Za postizanje postavljenog cilja treba provesti čitav niz postupaka koji se sastoje od preuređenja postojeće sekundarne (lokalne) cestovne mreže koju čine sabirne ulice, prilazne ulice i parkirališta, postavljanja posebne opreme za smirivanje prometa te uvođenja dosljedne i učinkovite regulative [3].

\section{Koncepcija smirivanja prometa}

\subsection{Reorganizacija postojeće cestovne mreže}

Sekundarnu (lokalnu) cestovnu mrežu čine sabirne ulice, prilazne ulice i parkirališta s osnovnom zadaćom omogućenja pristupa stambenim zonama, različitim urbanističkim sadržajima te zonama mirovanja vozila. $\mathrm{Na}$ ovoj mreži događa se značajan broj prometnih nesreća u kojima dominiraju konfliktni pješak-vozilo i/lil biciklistvozilo, a posljedice kojih mogu biti tragične. Za postizanje konačnog cilja smirivanja prometa u posebno osjetljivim dijelovima gradova poput stambenih naselja, područja škola ili dječjih vrtića i slično, osim uvođenja 
dosljedne i učinkovite regulative potrebno je (tamo gdje je to moguće napraviti) i reorganizirati postojeću mrežu pristupnih cesta.

Iskustvo je pokazalo da se smirivanje prometa na razini brzina kretanja $30 \mathrm{~km} / \mathrm{h}$ ili $40 \mathrm{~km} / \mathrm{h}$ ne može postići apeliranjem niti prisilom vozača. Ograničenja brzine zahtijevana prometnim znakovima vozači poštuju vrlo slabo ili nikako [1]. Brzinu kretanja vozači ostvaruju prema drugim cestovnim uvjetima i uvjetima okoliša, a ne prema prometnim znakovima, pa čak i ako takva ograničenja strogo i učestalo nadzire policija. Tako npr. kolnik veće širine, dulji ravni potezi, veći polumjeri zavoja i šira raskrižja vozače potiču na veće brzine vožnje.

Pješaci i vozila u kretanju i mirovanju mogu se djelomično razdvojiti uz ograničenje brzine kretanja vozila ( $v$ $\leq 30 \mathrm{~km} / \mathrm{h}$ ) ili potpuno integrirati na način zajedničkog korištenja prometne površine, ali pod uvjetima koji su prihvatjjivi pješacima i koji ih štite. Poprečni presjek pristupne ulice mora sadržavati funkcionalne elemente koji uvjetuju male brzine vožnje i zadovoljavaju potrebe vozila u mirovanju. U postupku reorganizacije poprečnog presjeka postojeće pristupne ulice, ograničavajući parametar je regulacijska širina same ulice, što uvjetuje organizaciju prometa (jednosmjerni, dvosmjerni) te sheme parkiranja.
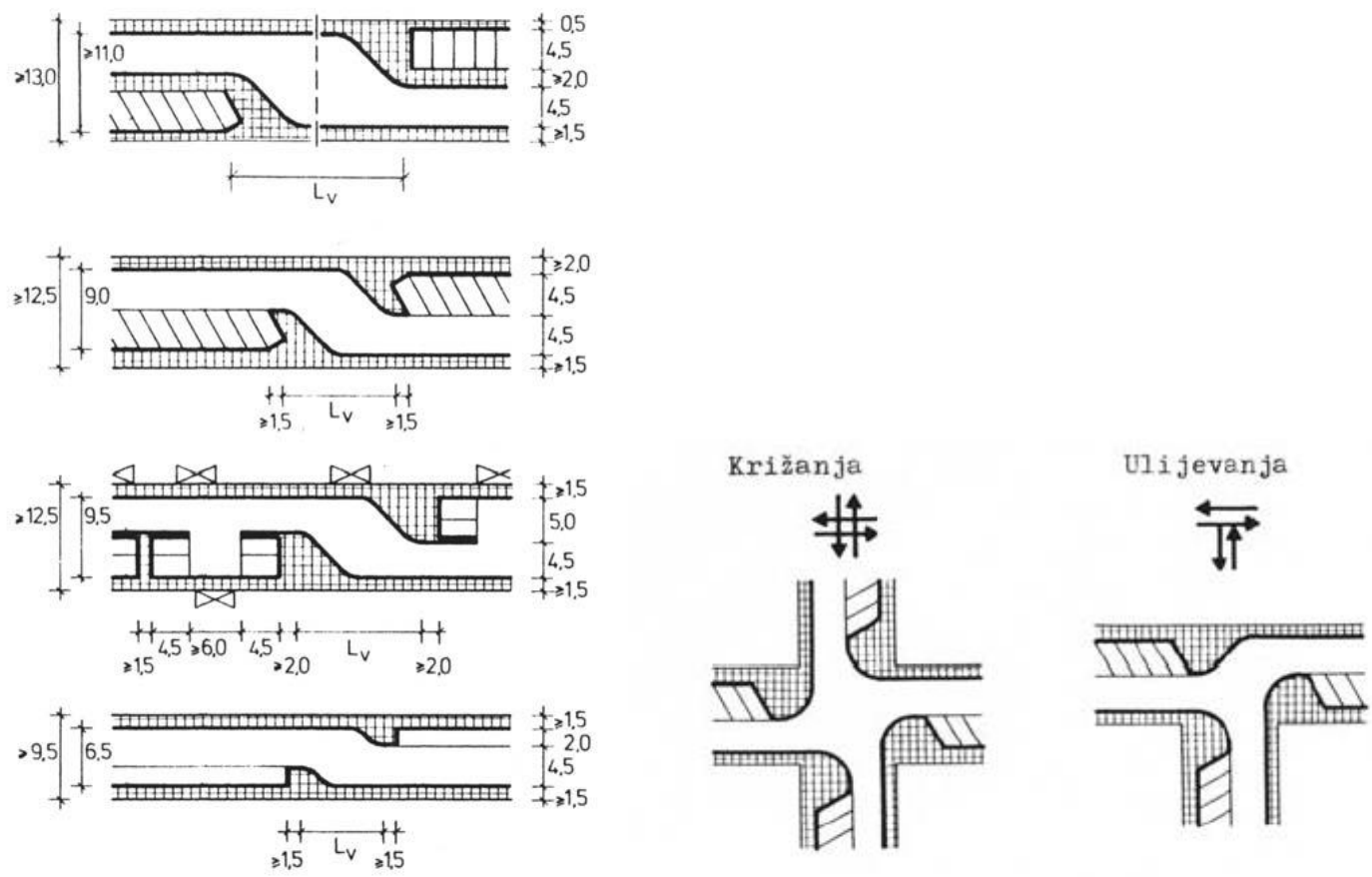

a)

b)

\section{Slika 2 - Smirivanje prometa reorganizacijom postojeće cestovne mreže [4]}

Glavni je zahtjev pristupnih ulica brzina kretanja koja iznosi $30 \mathrm{~km} / \mathrm{h}$ ili manje, te se svi granični elementi situacijskog plana tome moraju prilagoditi. U situacijskom planu svjesno se formira diskontinuitet kako bi vozači bili prisiljeni prilagoditi brzinu krivinskim oblicima ulice ili raskrižja. Takav primjer vidljiv je na slici 2. gdje su prikazane mogućnosti smirivanja prometa izvođenjem pomaka u vođenju osi ceste i naizmjeničnim parkiranjem koji ograničavaju pravocrtno protezanje dionice ulice (a) te primjer izvođenja pomaka na raskrižjima (b).

Svi elementi diskontinuiteta pristupnih ulica moraju biti posebno označeni tako da se vozačima na vrijeme skrene pozornost na ono što ih očekuje. To se izvodi sadnjom drveća, označivanjem kolnika, prometnim znakovima, osvjetljenjem i slično. Kako bi se dodatno smanjile brzine kretanja vozila, u području diskontinuiteta situacijskog plana izvodi se izdizanje kolnika. Kod projektiranja novih lokalnih mreža, dobar učinak ima i razdvajanje suprotno usmjerenih tokova u područjima mimoilaženja, a što je prikazano na slici 3. 


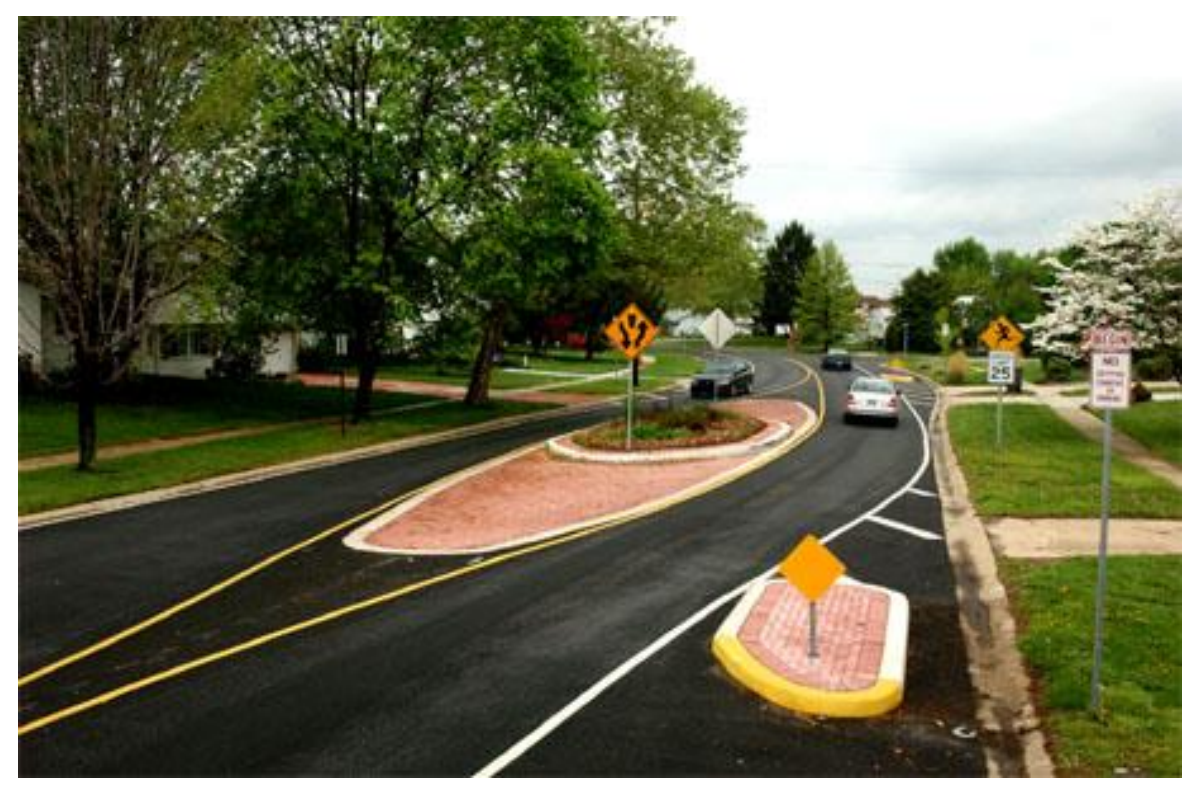

Slika 3 - Primjer razdvajanja smjerova vožnje izvođenjem prometnih otoka [5]

Sva rješenja problema ugroženosti nezaštićenih sudionika u prometu trebaju biti, u danim uvjetima, tehnički izvediva i jeftina te ne smiju ići na štetu ograničavanja propusne moći prometnice i pokretljivosti svih sudionika. Naime, ako je rješenje neudobno, motorizirani sudionici bi mogli početi izbjegavati određenu dionicu, a u tom slučaju bi svako smirivanje prometa izgubilo smisao jer bi postalo zabrana, nikako rješenje uvjetovanog kretanja.

\subsection{Mjere za smirivanje prometa}

Koncepcija smirivanja prometa kompromisno je rješenje nastalo iz potrebe za povećanjem sigurnosti sedamdesetih godina u zapadnoj Europi. Prije toga su inženjeri projektirali i gradili prometnice samo kako bi osigurali dobru pokretljivost, ali nisu se toliko obazirali na činjenicu da gradska prometnica nije namijenjena samo motornim vozilima već i svim ostalim oblicima prometa i sudionicima u njima.

Prvi organizirani planski pristup takve koncepcije bio je u Nizozemskoj u gradu Delftu; predstavljen je pod nazivom Woonerf model, a cilj je bio promijeniti navike vozača i učiniti stambene ulice sigurnijima za djecu, pješake i bicikliste. lako su čekali vladino odobrenje na program mjera gotovo čitavo desetljeće, koncepcija smirivanja prometa je uspješno provedena; postavljene su vreće s pijeskom, klupe te izgrađeni otoci za parkiranje. Na taj način je smiren promet, ali i smanjena buka koja nastaje prilikom kretanja vozila i direktno ovisi o brzini vozila.

Slijedom prihvaćenih mjera do 1990. godine je preoblikovano 3.500 ulica u nizozemskim gradovima, a do 2000. godine $10 \%$ od ukupnog broja ulica u naseljima. Nizozemski koncept se pokazao vrlo uspješnim i ubrzo se proširio po cijeloj Europi. U postupak planiranja i projektiranja koncepta smirivanja prometa uključili su se dizajneri i inženjeri kako bi svojim idejama vizualno i tehnički poboljšali početnu zamisao.

U želji da se koncepcija primijeni i na gradske ulice, koje su opterećenije prometom nego pristupne ulice unutar naselja, u Engleskoj je nastala ideja humpova ili izbočina za kontrolu brzine kretanja. Vrlo brzo su osmišljeni i izvedeni različiti oblici smirivanja prometa, od djelomičnih primjena u pojedinim slučajevima, do primjera preoblikovanja cijelih gradskih zona: petnaest gradskih zona diljem Nizozemske, među kojima $s$ najvećim opsegom zahvata gradovi Rijswijk i Eindhoven, pokrajina Nordrhein-Westfalen u Njemačkoj, ukupno $223 \mathrm{~km}$ cesta u zoni stanovanja u više gradova u Danskoj, primjena programa „Sigurniji grad, četvrti bez nezgoda" u dvadeset i šest gradova Francuske, gradovi London, Winchester i Lytham u Engleskoj [1]. 
Danas je moguće primijeniti čitav niz različith rješenja koja prisiljavaju vozače na smanjivanje brzine te povećavaju sigurnost ugroženih sudionika u prometu. Rješenja su sljedeća:

- proširenje nogostupa u odnosu na kolnik (slika 4) čime se izaziva učinak „uskog grla“ za vozače, a pješacima skraćuje prijelaz preko kolnika i smanjuje vrijeme njihove izloženosti;

- izbjegavanje vođenja osi ceste u pravcu, namjerno projektiranje „loma“, što prisiljava vozače na tzv."slalomsku vožnju" gdje je neophodno smanjivanje brzine. Moguće rješenje je i kombinacija izbočina na kolniku s organiziranim parkirališnim prostorom pri čemu parkirana vozila predstavljaju daljnju zapreku i uvjetuju kretanje vozila.

- prometni otoci za usmjeravanje vozila (slika 3);

- projektiranje i izvođenje kružnih raskrižja, posebno raskrižja s vanjskim promjerima $D_{v} \leq 35 \mathrm{~m}$ (mini i mala kružna raskrižja) u kojima je brzina vozila u kružnom toku v $\leq 30 \mathrm{~km} / \mathrm{h}$, čime se bitno povećava prometna sigurnost;

- izdignuća kolnika na široj površini (slika 5), gdje se različitim materijalima postiže denivelacija razine kolnika od 7-12 cm, ovisno o vrsti vozila za koju se predviđa izdignuće. Ovo, najviše korišteno tehničko rješenje, pojavljuje se u brojim modalitetima i izvedbama. Izdignute plohe kolnika izvode se čitavom širinom, najčešće od asfaltne ili betonske mase, moraju biti označene odgovarajućim prometnim znakovima i prometnom opremom, a svojom bojom se moraju razlikovati od površine na koju se ugrađuju [3]. Na kolniku se postavljaju i umjetne izbočine, popularnijeg naziva „ležeći policajci“, koje se izrađuju iz gumenih ili plastičnih masa.

- povećana uporaba kamenih kocaka na čitavom zastoru ili njegovim pojedinim dijelovima, a koje svojom teksturom stvaraju veće vibracije i buku te na taj način prisiljavaju vozača na smanjivanje brzine vožnje;

- uporaba vibracijskih traka prijelazom kojih se stvaraju vibracije neugodne za vozača te posredno djeluju na smanjenje brzine kretanja vozila;

- povećana uporaba različitih boja u oznakama prometnih površina, stupova, žardinjera, ograda.

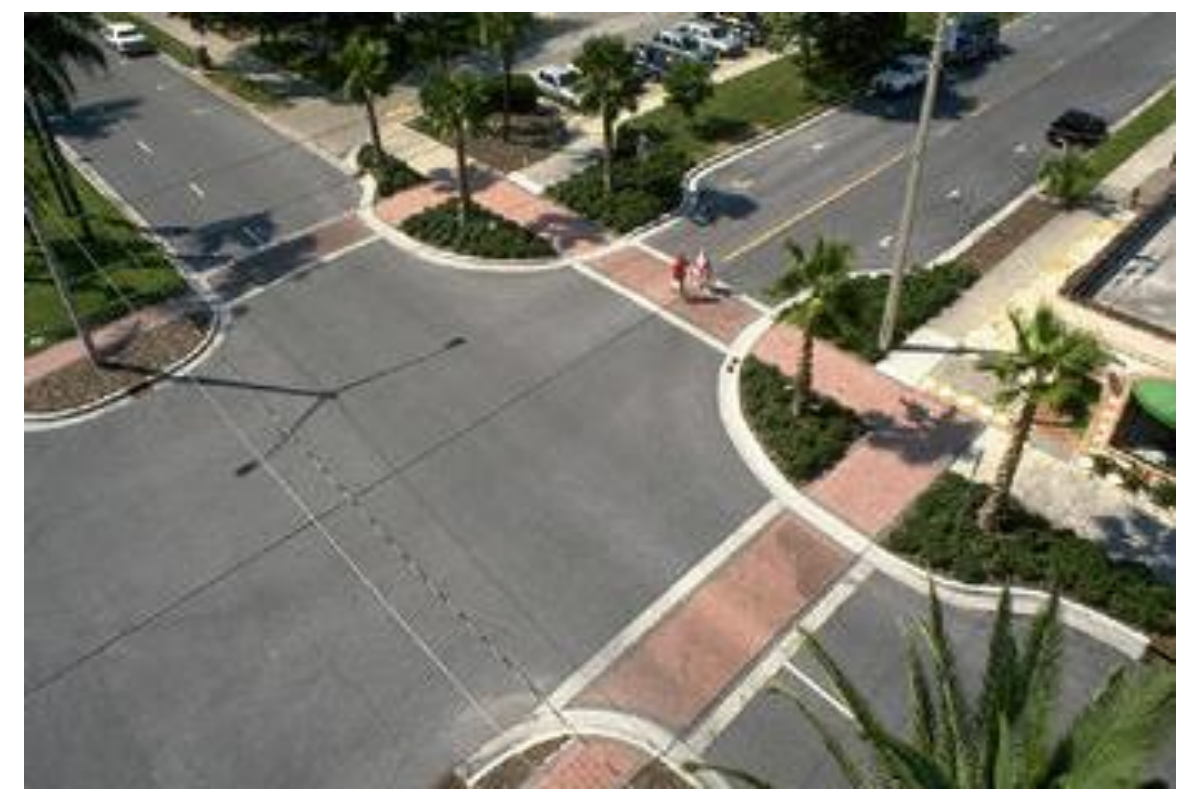

Slika 4 - Primjer suženja vozne i proširenja pješačke površine [6] 


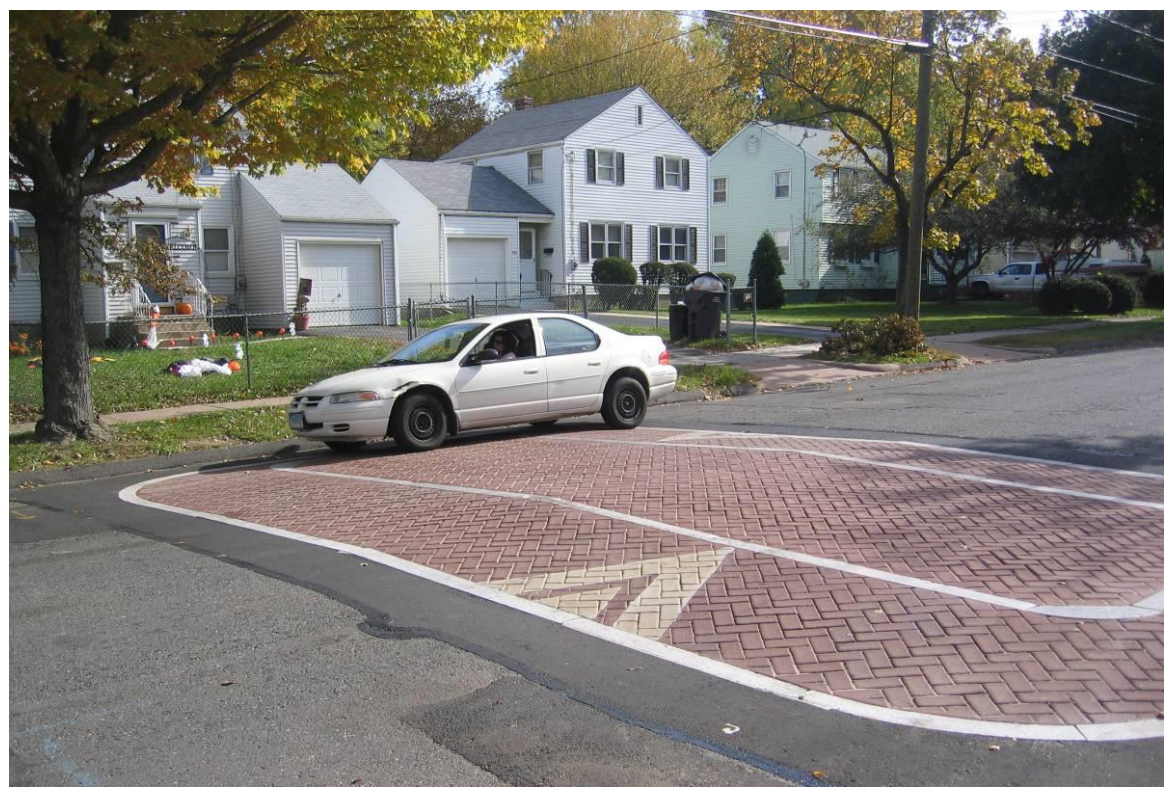

\section{Slika 5 - Izdignuće na kolniku izvedeno kombinacijom asfalta i betonskih elemenata [7]}

Uz sve navedene mogućnosti smirivanja prometa, i dalje se razmišlja o učinkovitim i jeftinim načinima smirivanja prometa pa je tako jedno neuobičajeno, a zanimljivo rješenje moguće vidjeti u manjim austrijskim mjestima gdje je ispred pješačkih prijelaza i škola postavljen dvodimenzionalni lik policajca u pravoj veličini.

\section{Smirivanje prometa u Republici Hrvatskoj}

\subsection{Osvrt na dosadašnja iskustva u smirivanju prometa}

U Republici Hrvatskoj ne postoji duga i sustavno izgrađivana tradicija u smirivanju prometa kao što je to slučaj u ostalim europskim zemljama. Intenzivnije bavljenje problematikom smirivanja prometa započinje u razdoblju od 1980.-1990. godine publiciranjem više radova različith autora (Brozović, Gledec, Mirić, Golubić, Divić i dr.) [4] kojima se ukazalo na potrebu uvođenja područja smirenog prometa i mjera smirenja prometa.

Prve mjere za smirivanje prometa bile su različith oblika i izvedbe, a i uspjesi koji su postignuti takvim mjerama bili su različiti. Prva praktična primjena smirivanja prometa u našim uvjetima [1] bila je primjena izbočina za kontrolu brzine u mjestu Cista Provo 1990. godine na raskrižju državnih cesta D 60 i D39, inače raskrižju na kojemu su se prosječno 10 puta godišnje događale prometne nesreće sa smrtnim posljedicama ili teškim povredama pješaka. Nakon uvođenja ove mjere smanjila se učestalost i prometnih nesreća i ozljeda. Slijedi mjera smirivanja prometa (originalna i jedinstvena) u Slavonskom Brodu, gdje kovinske kružne kalote širine oko $30 \mathrm{~cm}$, postavljene preko čitave širine kolnika na različitim mjestima u gradu, prisiljavaju vozače na smanjivanje brzine [1].

Prvi primjeri umjetnih izbočina (tzv."Iežeći policajci“) postavljeni su u Zagrebu, a ubrzo je u svim većim gradovima uslijedila njihova masovna primjena, posebno na cestama u blizini škola ili dječjih vrtića. Ovakav način umirivanja prometa bio je relativno jeftin i prilično učinkovit u dijelovima gdje su najčešći (i neoprezni) pješaci upravo djeca. Međutim, „ežeće policajace" se postavljalo bez prethodne analize opravdanosti i prometnog projekta, što je rezultiralo brojnim nedostacima i primjedbama: prolaz vozila preko izbočina bio je vrlo neudoban jer su vrlo visoke i neprimjerene ograničenju od $40 \mathrm{~km} / \mathrm{h}$, udarci su bili oštri čak i pri brzinama od samo 5 ili 10 $\mathrm{km} / \mathrm{h}$. Praksa primjene montažnih izbočina na kolniku ipak se u najvećoj mjeri zadržala do današnjih dana, praktično u svim sredinama.

lako su izbočine na kolniku vrlo popularno rješenje, zbog više razloga preporuča se da se već u postupku planiranja razmišlja o ostalim načinima smirivanja prometa kao što su suženje kolničkih površina, razdvajanje 
prometnih trakova otocima, prenamjena dijela vozne površine u parkirnu, zamjena klasičnih raskrižja kružnima i slično, a sve radi prisiljavanja vozača na tzv. slalomsku vožnju i smanjenje brzine.

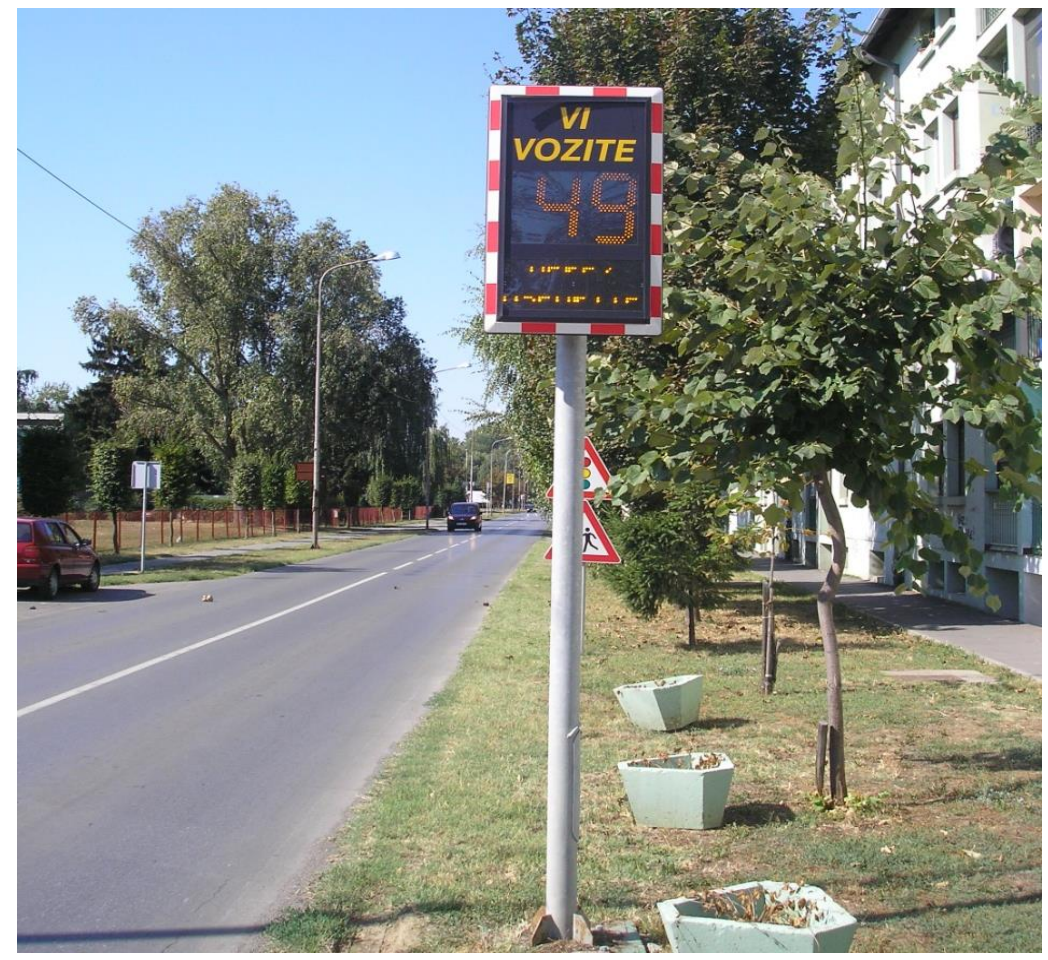

\section{Slika 6 - Smirivanje prometa uređajem za određivanje brzine vožnje}

Učinkovito rješenje smirivanja prometa u gradu Osijeku prikazano je na slici 6 . Kontrola i smirivanje prometa u Drinskoj ulici, u blizini osnovne škole, postignuta je postavljanjem uređaja za snimanje podataka o brzini vožnje koji skreće pozornost vozačima na brzinu kojom se kreću. Ako je ta brzina veća od $50 \mathrm{~km} / \mathrm{h}$, na semaforu koji se nalazi iza uređaja, a ispred škole, pali se crveno svjetlo i tako vozača prisiljava na zaustavljanje vozila.

\subsection{Zakonska i tehnička regulativa za smirivanje promet}

Tehničke mjere namijenjene smirivanju prometa u našim uvjetima prisutne su u Zakonu o sigurnosti prometa na cestama [8] i u Pravilniku o prometnim znakovima, signalizaciji i opremi na cestama [9]. Na nacionalnoj razini, a niti na regionalnim ili lokalnim razinama, kod nas nažalost ne postoje programi primjene mjera smirivanja prometa kao što je to redovito slučaj u razvijenim zemljama (SAD, Kanada, Danska, Nizozemska, Njemačka, Švicarska i dr.) [4].

Zakon o sigurnosti prometa na cestama [8] definira zonu smirenog prometa kao „područje u naselju obilježeno propisanim prometnim znakom, u kojem se vozila ne smiju kretati brzinom većom od brzine hoda pješaka i u kojem je dječja igra svugdje dopuštena". Prema navedenoj definiciji, ako je projektna brzina hoda pješaka $4,8 \mathrm{~km} / \mathrm{h}$, onda bi se u zonama smirenog prometa i motorna vozila trebala kretati tom brzinom, međutim u takvim je zonama istovremeno uvedeno ograničenje brzine kretanja najčešće $30 \mathrm{~km} / \mathrm{h}$ [10].

Isti zakon u članku 5. predviđa da predstavničko tijelo jedinice lokalne i regionalne samouprave, uz prethodnu suglasnost ministarstva nadležnog za unutarnje poslove, uređuje promet na svom području tako da određuje, između ostalog, i zone smirenog prometa.

Pravilnik o prometnim znakovima, signalizaciji i opremi na cestama [9] definira način označivanja naprava za smirivanje prometa te označivanja zona smirenog prometa. Prema članku 69. Pravilnika, naprave za smirivanje prometa, kao što su umjetne izbočine i uzdignute plohe, označuju se žutom bojom. U točki VI Pravilnika detaljno je opisana signalizacija i oprema za smirivanje prometa, a sastoji se od optičkih bijelih crta upozorenja, traka za zvučno upozoravanje, vibracijskih traka, umjetnih izbočina te uzdignutih ploha na kolniku. 
Optičke bijele crte upozorenja postavljaju se ispred raskrižja, pješačkih prijelaza, opasnog dijela ceste, ploče s nazivom naseljenog mjesta, cestarskih naplatnih mjesta, graničnih prijelaza i slično, a izvode se serijskim postavljanjem najmanje četiri bijele refleksivne trake poprečno na smjer vožnje preko cijele širine prometnog traka, sve veće širine i na sve manjem razmaku. Trake za zvučno upozoravanje vozača zbog svoje hrapave teksture pri prijelazu vozila proizvode tihe vibracije i zvučne efekte i time upozoravaju vozača da smanji brzinu. Postavljaju se ispred škola, vrtića, željezničkih prijelaza, pješačkih prijelaza, cestarskih naplatnih prolaza, križanja i opasnih zavoja. Vibracijske trake pri prijelazu vozila proizvode jače vibracije i zvučne efekte i time upozoravaju vozača da smanji brzinu. Umjetne izbočine se postavljaju preko polovine ili po cijeloj širini prometnog traka u stambenim ulicama, prije zona smirenog prometa, a njihova uporaba nije dopuštena u zoni bolnica, odnosno na cestama na kojima se češće kreću vozila Hitne pomoći. Uzdignute plohe se izvode pojedinačno ili u nizu, obično na mjestima gdje se nalazi obilježeni pješački prijelaz. Njihova površina mora biti od neklizajućeg materijala i označena stalnim reflektirajućim tvarima na onoj strani s koje se vozilo približava.

Uz opremu za smirivanje prometa, Pravilnikom [9] se definira i odgovarajuća vertikalna prometna signalizacija: znak „zona u kojoj je ograničena brzina“ na $30 \mathrm{~km} / \mathrm{h}$ (ovaj znak može biti iscrtan i horizontalno, na kolniku), znak „područje smirenog prometa“, znak „izbočina na cesti“. Na mjestima ugradnje umjetnih izbočina i uzdignutih ploha postavljaju se žuto-crvene ploče i na taj način dodatno upozorava vozače.

Svaki od navedenih načina za prisiljavanje vozača na smanjivanje brzine ima svoje prednosti, ali i nedostatke [10]. Provedena istraživanja su pokazala da odgovarajuća geometrijska struktura crta na kolniku (poput optičke bijele crte upozorenja) ne djeluju na svijest vozača i ne upozoravaju, nego djeluju nesvjesno, stvarajući iluziju kod vozača koji percipira sve manji i manji razmak između uzastopnih crta kao da povećava brzinu kretanja. Posljedica je automatska reakcija smanjivanja pritiska na papučicu gasa. Takva geometrijska struktura mora imati i odgovarajuću duljinu kako bi uopće bila učinkovita - oko $400 \mathrm{~m}$, a ne kao što se kod nas izvode - ne više od $100 \mathrm{~m}$ duljine.

Istraživanja [10] traka za zvučno upozoravanje pokazuju da su vibracije i zvukovi manji kada se preko njih prijeđe većom brzinom nego kod nižih brzina prolaza, jer to omogućuju napredni sustavi za amortizaciju i ogib kod suvremenih vozila.

Tehničke norme i standardi (treća normativna razina) koji reguliraju područje smirivanja prometa su od 1991. godine do 31.12.2008. bili JUS-evi u području smirivanja prometa (sukladno Zakonu o preuzimanju saveznih zakona iz oblasti prometa i veza koji se u Republici Hrvatskoj primjenjuju kao republički zakoni (NN 53/91)). Tim normama bilo je predviđeno pet tehničkih mjera čija su konstrukcijska rješenja propisivali sljedeći standardi: poprečne prepreke, prepreke na raskrižjima, suženja („otoci“ kao jedna od mjera smirivanja prometa na dionici), horizontalna skretanja (predviđene četiri moguće uzdužne devijacije na dionici prometnice) i vertikalne prepreke (djelomičan plato na kolniku čija visina ne smije prelaziti $5 \mathrm{~cm}$, ili puni plato na kolniku čija visina ne smije prelaziti $10 \mathrm{~cm}$ ). Posebnom odlukom Hrvatskog zavoda za normizaciju ove norme su povučene iz primjene, a nisu zamijenjene nekim sličnim hrvatskim normama, tako da od 1. siječnja 2009. do danas iz područja smirivanja prometa nema važeće norme [10].

Također, utvrđeno je da niti na jednoj razini ne postoje smjernice ili preporuke za primjenu mjera smirenja prometa kao ni kriteriji ili pregled raspoloživih mjera s načelnim ocjenama njihove učinkovitosti, odnosno povoljnosti primjene.

\section{Zaključak}

Dobro zamišljena i godinama usavršavana koncepcija smirivanja prometa, a poradi osiguranja najugroženijih sudionika u prometu, primjenjuje se u većini zemalja. Osim građevinskih zahvata kojima je moguće reorganizirati postojeću sekundarnu mrežu prometnica, smirivanje prometa postiže se i čitavim nizom mjera kojima se ne djeluje samo na svijest i savjest vozača, već ih se potiče na nesvjesno smanjivanje brzine kretanja u susretu s različitim oblicima cestovnih barijera [11].

Sve mjere za smirivanje prometa imaju prvenstveno cilj prisiliti vozače na smanjenje brzine kretanja motornih vozila te na taj način zaštititi sve ugrožene nemotorizirane sudionike prometa, posebno u stambenim zonama i zonama škola i dječjih vrtića. Osim ovog osnovnog cilja, smirivanjem prometa moguće je postići povećanje udobnosti (osobito osjećaja sigurnosti kod pješaka) pješačkih komunikacija te smanjenje neposrednih 
štetnih utjecaja na okoliš slijedom općenitog smanjenja brzine, ali i ujednačenijih prometnih tokova s obzirom na brzinu. Smanjenjem brzine smanjuje se razina buke te onečišćujući sastojci ispušnih plinova i čestica kao što su sumporni spojevi, ugljični oksidi, dušični oksidi, olovni spojevi, čađa i dim i slično.

Za razliku od većine europskih zemalja u kojima postoji dobra zakonska i tehnička regulativa za primjenu mjera smirivanja prometa, u Republici Hrvatskoj je situacija nešto drugačija. Normativni okvir za smirivanje prometa je vrlo skučen, smjernica ili preporuka za primjenu mjera smirivanja prometa nema, kao ni tehničke norme koja bi regulirala ovo područje.

Sukladno svemu iznesenom, jedini poticaj za moguće uvođenje mjera smirivanja prometa kod nas kreće od stanovnika koji žive u neposrednoj blizini incidentnih mjesta (ili su ta mjesta po njihovoj subjektivnoj ocjeni incidentna), odnosno od korisnika pojedinih institucija kao što su roditelji djece koja polaze škole ili vrtiće, učitelji ili ravnatelji škola. Skorim ulaskom Republike Hrvatske u Europsku Uniju svakako će se intenzivirati rad na tehničkoj regulativi iz područja smirivanja prometa, a sve poradi osiguranja boljih uvjeta stanovanja i zaštite nezaštićenih sudionika u prometu, posebno onih najmlađih i najneopreznijih.

\section{Literatura}

[1] Smirivanje prometa, Publikacija, Grad Zagreb - Gradski sekretarijat za graditeljstvo, komunalne i stambene poslove, promet i veze, Zagreb, 1994.

[2] Kenjić, Z. 2009. Kružne raskrsnice - rotori, Priručnik za planiranje i projektovanje, Sarajevo

[3] Legac, I. i koautori. 2011. Gradske prometnice, Sveučilište u Zagrebu Fakultet prometnih znanosti, Zagreb

[4] Brozović, I. 2010. Planiranje u urbanom prostoru i prometna infrastruktura, skripta, Građevinski fakultet u Rijeci

[5] http://www.deldot.gov/information/projects/outstanding_projects/2001/ (27.08.2011.)

[6] http://www.pps.org/articles/livememtraffic/\#ROAD\%20HUMPS,\%20SPEED\%20TABLES,\%20AND\%20CUSH IONS (27.08.2011.)

[7] http://www.vtpi.org/tdm/tdm4.htm (27.08.2011.)

[8] Zakon o sigurnosti prometa na cestama (NN 67/08, 74/11)

[9] Pravilnik o prometnim znakovima, signalizaciji i opremi na cestama (NN. 33/05)

[10] Gledec, M. 2010. Smirivanje prometa: smjernice za primjenu mjera, Ministarstvo unutarnjih poslova Republike Hrvatske, Zagreb

[11] Lukač, R. 2011. Smirivanje prometa u gradovima, Završni rad, Građevinski fakultet Osijek 